\title{
Commentaries
}

\section{Social Psychological Perspectives on Trump Supporters}

\author{
Thomas F. Pettigrew ${ }^{\text {a }}$ \\ [a] Department of Psychology, University of California, Santa Cruz, CA, USA.
}

\begin{abstract}
No one factor describes Trump's supporters. But an array of factors - many of them reflecting five major social psychological phenomena can help to account for this extraordinary political event: authoritarianism, social dominance orientation, prejudice, relative deprivation, and intergroup contact. Research on the topic demonstrates that these theories and concepts of social psychology prove centrally important in helping to understand this unexpected event. This paper describes the supporting data for this statement and demonstrates the close parallels between these American results and those of research on far-right European supporters.
\end{abstract}

Keywords: authoritarianism, social dominance orientation, prejudice, relative deprivation, intergroup contact, Trump supporters

Journal of Social and Political Psychology, 2017, Vol. 5(1), 107-116, doi:10.5964/jspp.v5i1.750

Received: 2017-01-04. Accepted: 2017-02-22. Published (VoR): 2017-03-02.

Handling Editor: J. Christopher Cohrs, Philipps University Marburg, Marburg, Germany

*Corresponding author at: Department of Psychology, High Street, University of California, Santa Cruz, CA, 95064, USA. E-mail: pettigr@ucsc.edu

(i) This is an open access article distributed under the terms of the Creative Commons Attribution License

(http://creativecommons.org/licenses/by/3.0), which permits unrestricted use, distribution, and reproduction in any medium, provided the original work is properly cited.

Social scientists are keenly aware that the world is exceedingly complex, that virtually all social phenomena are multivariate. Understanding Trump's supporters is no exception. We must consider an array of interrelated factors to account for this unprecedented election - demographic and individual factors that constituted the tinder for the explosion and the actual igniting factors that lit the fire. Research on the topic demonstrates that numerous theories and concepts of social psychology prove centrally important in helping to understand this unexpected event. But no claim is made that these social psychological factors provide in themselves a complete explanation. Obviously, key political variables are also involved (Norpoth, 2016), and these are intertwined with the social psychological variables to be evaluated in this paper.

\section{The Tinder}

The Trump movement is not singular within the United States (the Know Nothing movement in the 1850s, the Wallace movement in the 1960s, and the more recent Tea Party Movement). Moreover, other democracies have seen similar movements (e.g., Austria's Freedom Party, Belgium's Vlaams Blok, France's National Front, Germany's 
Alternative for Germany Party (AfD), and Britain's U.K. Independence Party (UKIP). In virtually all these cases, the tinder especially involved male nativists and populists who were less educated than the general population. But this core was joined by other types of voters as well. Five highly interrelated characteristics stand out that are central to a social psychological analysis - authoritarianism, social dominance orientation, outgroup prejudice, the absence of intergroup contact and relative deprivation.

\section{Authoritarianism and Social Dominance Orientation (SDO)}

Authoritarianism is an intensely studied syndrome the effects of which are surprisingly consistent across the globe (Adorno, Frenkel-Brunswik, Levinson, \& Sanford, 1950; Allport, 1954; Altemeyer, 1981, 1988, 1996). Several traits characterize the syndrome: deference to authority, aggression toward outgroups, a rigidly hierarchical view of the world, and resistance to new experience. Authoritarianism is typically triggered by threat and fear (Feldman \& Stenner, 1997; Stenner, 2005), and authoritarians tend to view the world as a very dangerous and threatening place (Allport, 1954).

There is debate as to whether to consider authoritarianism a personality construct or a political ideology in itself. However, there is no necessary conflict between these two perspectives (Pettigrew, 2016). Authoritarianism begins early in life as a personality orientation - witness its genetic roots (Ludeke \& Krueger 2013; McCourt, Bouchard, Lykken, Tellegen, \& Keyes, 1999). And later this orientation typically leads to some form of a right-wing political ideology. Purely personality measures of authoritarianism are needed now to complement these political attitude assessments; and two such promising scales are now available (Feldman \& Stenner, 1997; Oesterreich, 2005). These scales eliminate the political content of earlier measures.

Authoritarianism has been successfully measured in different ways. Political scientists prefer to ask about what is more important for children - respect for elders more important than independence; obedience more important than self-reliance; to be well-behaved more important than being creative; and to have good manners more important than to be curious (Feldman, in press; Feldman \& Stenner, 1997).

Social psychologists prefer such items as: "The authorities should be obeyed because they are in the best position to know what is good for our country"; and "Obedience and respect for authority are the most important virtues children should learn." These methodological approaches are highly interrelated and both have proven useful. And note that they overlap in their attention to basic values.

SDO is closely related to authoritarianism but clearly separable (Duckitt \& Sibley, 2007; Sidanius \& Pratto, 2001). It features an individual's preference for the societal hierarchy of groups and domination over lower-status groups. It represents a predisposition toward anti-egalitarianism within and between groups. Individuals who score high in SDO are typically dominant, driven, tough-minded, disagreeable, and relatively uncaring seekers of power. They believe in a "dog-eat-dog" world, and they report being motivated by self-interest and self-indulgence (Levin, Federico, Sidanius, \& Rabinowitz, 2002).

Though found among left-wingers (e.g., Dusso, 2017), authoritarianism is more numerous among right-wingers throughout the world (Meloen, 1993). Trump's speeches, studded with such absolutist terms as "losers" and "complete disasters," are classic authoritarian statements. His clear distinction between groups on the top of society (Whites) and those "losers" and "bad hombres" on the bottom (immigrants, Blacks and Latinos) are classic social dominance statements. 
In the United States, Republicans began averaging higher on authoritarianism than Democrats before the rise of Trump (Hetherington \& Weiler, 2009). And the party began to learn how to appeal to this segment of the American electorate in various ways. The Republican Party's opposition to virtually everything proposed by the AfricanAmerican President Obama helped. But it remained for Trump to break the unwritten rules of American politics and appeal directly and openly to authoritarians and those who score high on SDO.

Not surprisingly, recent work reveals that Trump supporters tend to be especially high scorers on both scales. Eight months prior to the election, MacWilliams (2016) relied on his survey finding - that high authoritarians were strongly in favor of Trump - to predict correctly that routine election surveys were sharply underestimating Trump's support. During the presidential primaries in February 2016, Feldman (in press) also found a significant positive relationship between authoritarianism and favorable evaluations of Trump among Republicans. Indeed, none of the evaluations of the other primary candidates revealed such a connection.

In agreement, Choma and Hanoch (2017), analyzing data from a Mechanical Turk sample of 406 American adults, found that both authoritarianism $(r=+.46)$ and SDO $(r=+.48)$ correlated highly $(p<.001)$ with the intention to vote for Trump. Similarly, Van Assche and Pettigrew (2016) gathered another Mechanical Turk sample of 139 White American adults and found authoritarianism $(r=+.47)$ and SDO $(r=+.32)$ correlated highly $(p<.001)$ with planning to vote for Trump. This consistency across these various studies is noteworthy because they employed different measures of the key predictor variables. The first two of the studies cited above employed Feldman's political science measure of authoritarianism, while the other two studies used standard social psychological items. The last two studies also employed somewhat different SDO items.

The joint power of authoritarianism and SDO to predict far-right-wing voting has also been repeatedly found in European research - in Belgium and France (Lubbers \& Scheepers, 2002; Swyngedouw \& Ivaldi, 2001; Van Hiel, 2012; Van Hiel \& Mervielde, 2002), the Netherlands (Cornelis \& Van Hiel, 2015) and Italy (Leone, Desimoni, \& Chirumbolo, 2014). Thus, the American data are not unique.

\section{Prejudice}

Many outgroup prejudices characterize dedicated Trump's followers, not just anti-immigrants, but anti-outgroups in general. Since Richard Nixon's "southern strategy," the Republican Party has employed strategies that appeal to bigotry with "dog whistles" - somewhat subtle codewords for race and other minorities designed to be heard by racists but not by non-racists. Nixon opposed racial school desegregation by claiming to be against the "bussing" needed to achieve interracial schools. Ronald Reagan began his campaign in 1980 by giving a "states' rights" speech in Philadelphia, Mississippi quite near where three civil rights workers had been lynched earlier. George H. W. Bush in 1988 ran a campaign ad of an African-American murderer that his opponent had released from jail - an ad for which his campaign manager later apologized.

The 2008 presidential campaign witnessed recurrent Republican slips that betrayed traditional racist thinking (Pettigrew, 2009; Staples, 2008). One Republican club issued false ten dollar bills with Obama's picture accompanied by stereotyped African-American food - a watermelon, ribs and a bucket of fried chicken. The McCain campaign ran an advertisement claiming that Obama had been "disrespectful" to Governor Palin - the old Southern term recalling sanctions against Black men interacting with White women. Republican Representative Lynn Westmoreland described Obama and his wife as "uppity." And Republican Representative Geoff Davis called the then-47-year-old Obama, "Boy." 
Trump is less subtle. He has repeatedly made unconcealed use of prejudice against outgroups ranging from "dangerous" Muslims to Mexican "rapists." His dedicated followers loved it; breaking with so-called "political correctness," he blared openly what they had been saying privately.

Not surprisingly, then, support for Trump correlates highly with a standard scale of modern racism $(r=+.48$; Van Assche \& Pettigrew, 2016). And once again a European study is congruent with this American finding. Billiet and De Witte (2008) found that prejudice against immigrants was the single most important predictor of support for the far-right Vlamms Blok Party in Flemish Belgium.

Data from France's 2012 presidential election strongly indicates that the racist National Front campaign of Marine Le Pen moved perceptions of social norms to the political right (Portelinha \& Elcheroth, 2016). It appears that Trump, too, has eroded norms that proscribed intolerant speech and behavior. Racist graffiti, threats and hate crimes all rose sharply following Trump's election victory (Reilly, 2016).

In addition, pre-election publicity that minorities were planning to vote in large numbers for Clinton undoubtedly stirred Republicans to turn out too. In fact, the African-American turnout fell below that of 2008 and 2012 - a key factor in Clinton's narrow losses in North Carolina, Michigan and Pennsylvania.

\section{Intergroup Contact}

A major means of reducing intergroup prejudice is through optimal intergroup contact (Pettigrew, 1998; Pettigrew \& Tropp, 2006, 2011). So it is noteworthy that there is growing evidence that Trump's White supporters have experienced far less contact with minorities than other Americans. For instance, Rothwell and Diego-Rosell (2016, p. 14) found that "...the racial and ethnic isolation of Whites at the zip-code level is one of the strongest predictors of Trump support." This finding remains true for both non-Hispanic Whites in general and for the smaller subset of White Republicans. And this lack of intergroup contact result emerges while controlling for dozens of other variables.

Consistent with this finding, these researchers also found that Trump support increased as an area's distance from the Mexican border increased. Throughout the world, intergroup contact has been shown typically to diminish prejudice by reducing intergroup fear and inducing empathy (Pettigrew \& Tropp, 2008, 2011). Its extreme absence for most Trump fans is an important factor that has been virtually ignored in the post-election analyses.

Interestingly, a similar finding emerged in research on the United Kingdom's Brexit vote to leave the European Union (EU). The extent of voters' social networks and their propensity to travel beyond their hometown had stronger negative effects than income in shaping their nationalistic, populist, anti-immigrant support for leaving the EU. But those who had spent time with a foreigner were $15 \%$ less likely to have voted to leave (Maguire, 2016). We return later for further analysis of the Brexit vote.

\section{Relative Deprivation}

The principal media explanation for explaining Trump's followers involves economics. Trump loyalists were assumed to have lost their jobs to Mexico and China and to be understandably angry. Little mention was made of the major reason for massive job losses - the accelerating pace of automation.

Mass media writers, reading each other and non-randomly interviewing a few unemployed workers, latched on to this too-simple theory as the primary explanation for the Trump victory. Single-factor theories are always dubious 
(Pettigrew \& Hewstone, 2017). The claim was that economically-deprived and often unemployed, angry workingclass voters in basic manufacturing areas switched political parties and voted for "change." This argument ignored the fact that the greatly depleted power of labor unions (by 2016 , down to only $10.7 \%$ of wage and salary workers) to help turn out the Democratic vote was a significant factor - especially in key industrial states.

Undoubtedly, this media caricature fits some followers, especially in the swing states of Michigan, Ohio, Pennsylvania, and Wisconsin. But this contention does not provide the major explanation for Trump's support. The argument lost much of its credence when Silver (2016) estimated that the median annual income of Trump supporters was a solid $\$ 72,000$. The most impressive and extensive study of voting intentions later provided an estimate of $\$ 81,898$ for Trump backers' mean household income. Instead of being far poorer than Clinton voters, this figure was slightly above the $\$ 77,046$ for those who had an unfavorable view of Trump (Rothwell \& Diego-Rosell, 2016).

Rothwell and Diego-Rosell (2016) analyzed in detail the individual and geographic data of 125,000 American adults who had answered Gallup survey phone calls during the long election period. Many of their results challenge the widespread view of Trump supporters. Trump followers were less likely than others to be looking for work, unemployed or part-time employed. And those voters living in districts with more manufacturing were actually less favorable to Trump. Nor were his followers largely living and working in postal areas where employment in manufacturing had declined since 1990. Underlying these results is the fact that blue-collar Trump supporters tend to work in occupations that are largely shielded from Chinese and Mexican competition - transportation, repair, and construction (Rothwell \& Diego-Rosell, 2016).

To be sure, social mobility has been declining in the United States. Contrary to the popular too-simple theory, however, people who live in areas with greater mobility voted more Republican (Campante \& Yanagizawa-Drott, 2016). This was even true in the crucial "swing states," and it is a trend that can be detected in other recent elections.

But these findings do not mean that social class and economics played no role whatsoever in this tight election. Instead of absolute deprivation, social psychologists stress the importance of relative deprivation. Disappointing comparisons to relevant referents is often more significant than factual changes (Pettigrew, 2015, 2016; Smith, Pettigrew, Pippin, \& Bialosiewicz, 2012). What voters think is true is more important in elections than the actual truth.

Trump adherents feel deprived relative to what they expected to possess at this point in their lives and relative to what they erroneously perceive other "less deserving" groups have acquired. Rapidly rising costs of housing and prescription drugs have aggravated their financial concerns. Their savings may not allow the type of ideal retirements they had long envisioned. And hopes for their children advancing beyond their status and going to college are being dashed by rising tuitions.

Building on the research of Chetty and Hendren (2016), Rothwell and Diego-Rosell (2016) found that Trump actually did better in some low mobility areas (e.g., Raleigh, Indianapolis and rural areas generally) where children are having difficulty just reaching the status of their parents. Working-class families had previously depended on low-tuition state institutions of higher learning for educational and employment mobility. But largely Republican state legislatures throughout the country have sharply reduced funding to these schools, forcing rising tuitions. Thus, Trump adherents are typically not personally economically destitute; but they are, as Thomas Edsall (2016) phrased it, "falling behind the Joneses." In short, they were often feeling deprived relative to their hopes and expectations. 
Trump exploited this sense of relative deprivation brilliantly. He articulated issues snugly within the authoritarian worldview of his admirers. His words and claims appalled many Americans, but he knew his target audience well. In their insightful analysis, Reicher and Haslam (2016) describe Trump's carefully staged rallies in detail. Calling them "identity festivals" that embodied a politics of hope, they note how they were choreographed to bind the attendees into a populist movement with the media (forced to sit in a cordoned-off back section), immigrants, and the so-called "elite" as enemies. Criticism of Trump by the media and other sources (such as Clinton calling some of his followers "deplorables") only enhanced the movement and served to confirm Trump's assertions against their common "enemies."

Trump's oft-repeated slogan, "Make America great again," augmented the movement's thrust. It represented a brash reactionary call to return to an earlier time when America's position in the world was unchallenged, when American presidents and Supreme Court judges were all White males, when immigration was restricted and widespread racial segregation persisted, and when the government's affirmative action programs largely helped White males (e.g., the G.I. Bill of Rights, Federal housing loans). And his cabinet heads suggest that Trump plans to return to that long-ago scene as much as possible.

\section{The Spark}

All five of these tightly interconnected phenomena - authoritarianism, social dominance, prejudice, lack of intergroup contact and relative deprivation - make people vulnerable to an intense sense of threat. Authoritarian leaders have long understood that they can attract followers by enhancing the perception of dangerous threats to the society and offering simple solutions (Mols \& Jetten, 2016). Sometimes the threats are real (Hitler with massive Weimar inflation), but often they are imagined (Trump with patently false claims of a declining economy, massive voter fraud, enormously increased crime, and unvetted immigration). With a background of genuine terrorist threats, Mideast conflict, and a recent great recession, even imagined threats seem plausible - especially to citizens who are already easily threatened and who have witnessed rapid change in their localities.

Consider again the U.K. Brexit vote. Urban areas, such as London, with large, established immigrant populations voted strongly to remain in the European Union (EU); while areas with relatively few immigrants voted heavily to leave the EU. But when a longitudinal analysis is applied, the key variable emerges: the speed of change in the immigrant population. Areas with modest immigrant populations in 2000 that had witnessed more than a $200 \%$ rise in immigrants by 2015 voted an astounding $94 \%$ to leave the EU (Economist Staff, 2016). This striking result is an example of the delicate balance between threat and contact - the dual effects of diversity (Green, Sarrasin, Baur, \& Fasel, 2016; Pettigrew \& Hewstone, 2017; Wagner, Christ, Pettigrew, Stellmacher, \& Wolf, 2006). London and other major English cities had had long experience with immigrants, and had increased their diversity relatively gradually. Time had reduced the sense of threat and enhanced positive intergroup contact. But for small towns and rural districts with a sudden and rapid entry of immigrants, perceived threat prevailed and optimal contact was as yet minimal.

A quite similar process occurred in small Midwestern towns with rapid increases in Latino immigration. According to Adamy and Overberg (2016b), areas whose diversity index rose by $150 \%$ witnessed a $67 \%$ vote for Trump. Consider Arcadia, Wisconsin, that had job growth - not restricted jobs (Adamy \& Overberg, 2016a). Arcadia's plentiful jobs attracted rapid in-migration from below the Mexican border - roughly 1,500 miles away. The resulting 
perceived threat, unalleviated by a period of intergroup contact, made many rural and small-town White Midwesterners respond positively to Trump's harsh anti-immigrant rhetoric. This interpretation is supported by the macrofindings of Rothwell and Diego-Rosell (2016) discussed above.

\section{A Final Word}

No one factor describes Trump's supporters. But an array of factors - many of them reflecting five major social psychological phenomena that form the tinder and the spark - can help to account for this extraordinary political event.

These social psychological factors are not unique to the United States. We have seen throughout the paper that many studies of Europe's far-right-wing voters show results strikingly similar to these data on the 2016 American election. Authoritarianism and social dominance attitudes have been routinely found to correlate significantly with far-right voting in nations throughout Europe. These voters share with Trump supporters similar views of women, minorities, immigrants, and free-market economics. Three major Populist-like grievances of Europe's far-right arise from economic changes, political elitism and immigration - with immigration the most intense issue (Ivarsflaten, 2008). American research suggests that the same can be said about the Trump movement.

The implications of this analysis for scholars who study these political phenomena in democracies are three-fold. First, despite vast differences in political structures and economic circumstances between Western nations, there are a surprising number of important similarities across these various populist political movements.

Second, these similarities suggest that those conducting research on one such movement might well look to work in other countries for additional variables. For instance, the importance of relative deprivation for understanding Trump supporters offers a possible research approach that has been seldom employed in European work.

Finally, the actual operation of the five social psychological variables and theories detailed in this paper need to be integrated within a broad political context. Political and social psychological approaches are mutually supportive - not anti-thetical. Future research must bring them together in multi-level models.

\section{Funding}

The author has no funding to report.

\section{Competing Interests}

The author has declared that no competing interests exist.

\section{Acknowledgments}

The author has no support to report. 


\section{References}

Adamy, J., \& Overberg, P. (2016a, November 1). Places most unsettled by rapid demographic change are drawn to Donald Trump. Wall Street Journal. Retrieved from

https://www.wsj.com/articles/places-most-unsettled-by-rapid-demographic-change-go-for-donald-trump-1478010940

Adamy, J., \& Overberg, P. (2016b, November 9). Counties that experienced rapid diversification voted heavily for Donald Trump. Wall Street Journal. Retrieved from

https://www.wsj.com/articles/counties-that-experienced-rapid-diversification-voted-heavily-for-donald-trump-1478741076

Adorno, T. W., Frenkel-Brunswik, E., Levinson, D. J., \& Sanford, R. N. (1950). The authoritarian personality. New York, NY, USA: Harper \& Row.

Allport, G. W. (1954). The nature of prejudice. Reading, MA, USA: Addison-Wesley.

Altemeyer, B. (1981). Right-wing authoritarianism. Winnipeg, Canada: University of Manitoba Press.

Altemeyer, B. (1988). Enemies of freedom: Understanding right-wing authoritarianism. San Francisco, CA, USA: Jossey-Bass.

Altemeyer, B. (1996). The authoritarian specter. Cambridge, MA, USA: Harvard University Press.

Billiet, J., \& De Witte, H. (2008). Everyday racism as predictor of political racism in Flemish Belgium. The Journal of Social Issues, 64(2), 253-267. doi:10.1111/j.1540-4560.2008.00560.x

Campante, F., \& Yanagizawa-Drott, D. (2016, December 9). Did declining social mobility cause Trump's rise? In a word, no. Vox. Retrieved from http://www.vox.com/the-big-idea/2016/12/9/13895184/social-mobility-economic-anxiety-trump-chetty

Chetty, R., \& Hendren, N. (2016). The impacts of neighborhoods on intergenerational mobility II: County-level estimates (National Bureau of Economic Research [NBER] Working Paper No. 23002). Retrieved from http://www.nber.org/papers/w23002

Choma, B. L., \& Hanoch, Y. (2017). Cognitive ability and authoritarianism: Understanding support for Trump and Clinton. Personality and Individual Differences, 106, 287-291. doi:10.1016/j.paid.2016.10.054

Cornelis, I., \& Van Hiel, A. (2015). Extreme-right voting in Western Europe: The role of social-cultural and antiegalitarian attitudes. Political Psychology, 36(6), 749-760. doi:10.1111/pops.12187

Duckitt, J., \& Sibley, C. G. (2007). Right wing authoritarianism, social dominance orientation and the dimensions of generalized prejudice. European Journal of Personality, 21, 113-130. doi:10.1002/per.614

Dusso, A. (2017). Race and right-wing authoritarianism: How scoring high on authoritarianism does not necessarily lead to support for right-wing candidates. Social Science Quarterly, 98, 244-260. doi:10.1111/ssqu.12302

Economist Staff. (2016, July 16). The immigration paradox. The Economist, p. 48.

Edsall, T. B. (2016, July 7). How falling behind the Joneses fueled the rise of Trump. New York Times. Retrieved from https://www.nytimes.com/2016/07/07/opinion/campaign-stops/how-falling-behind-the-joneses-fueled-the-rise-of-trump.html

Feldman, S. (in press). Authoritarianism, threat, and intolerance. In E. Borgida, C. Federico, \& J. Miller (Eds.), At the forefront of political psychology: Essays in honor of John L. Sullivan. New York, NY, USA: Routledge.

Feldman, S., \& Stenner, K. (1997). Perceived threat and authoritarianism. Political Psychology, 18, 741-770. doi:10.1111/0162-895X.00077

Journal of Social and Political Psychology

2017, Vol. 5(1), 107-116

doi:10.5964/jspp.v5i1.750 
Green, E. G. T., Sarrasin, O., Baur, R., \& Fasel, N. (2016). From stigmatized immigrants to radical right voting: A multilevel study of the role of threat and contact. Political Psychology, 37(4), 465-480. doi:10.1111/pops.12290

Hetherington, M. J., \& Weiler, J. D. (2009). Authoritarianism and polarization in American politics. New York, NY, USA: Cambridge University Press.

Ivarsflaten, E. (2008). What unites right-wing populists in Western Europe? Re-examining grievance mobilization models in seven successful cases. Comparative Political Studies, 41(1), 3-23. doi:10.1177/0010414006294168

Levin, S., Federico, C. M., Sidanius, J., \& Rabinowitz, J. L. (2002). Social dominance orientation and intergroup bias: The legitimation of favoritism for high-status groups. Personality and Social Psychology Bulletin, 28(2), 144-157.

doi:10.1177/0146167202282002

Lubbers, M., \& Scheepers, P. (2002). French Front National voting: A micro and macro perspective. Ethnic and Racial Studies, 25(1), 120-149. doi:10.1080/01419870120112085

Ludeke, S. G., \& Krueger, R. F. (2013). Authoritarianism as a personality trait: Evidence from a longitudinal behavior genetic study. Personality and Individual Differences, 55, 480-484. doi:10.1016/j.paid.2013.04.015

Leone, L., Desimoni, M., \& Chirumbolo, A. (2014). Interest and expertise moderate the relationship between right-wing attitudes, ideological self-placement and voting. European Journal of Personality, 28, 2-13. doi:10.1002/per.1880

MacWilliams, M. (2016, January 17). The one weird trait that predicts whether you're a Trump supporter. Politico Magazine. Retrieved from http://www.politico.com/magazine/story/2016/01/donald-trump-2016-authoritarian-213533

Maguire, P. (2016, December 17). Socially isolated voters more likely to favour Brexit, finds thinktank. Guardian. Retrieved from https://www.theguardian.com/politics/2016/dec/17/socially-isolated-voters-more-likely-to-favour-brexit-finds-thinktank

Meloen, J. D. (1993). The F scale as a predictor of fascism: An overview of 40 years of authoritarian research. In W. F. Stone, G. Lederer, \& R. Christie (Eds.), Strength and weakness (pp. 47-69). New York, NY, USA: Springer.

McCourt, K., Bouchard, T. J., Jr., Lykken, D. T., Tellegen, A., \& Keyes, M. (1999). Authoritarianism revisited: Genetic and environmental influences examined in twins reared apart and together. Personality and Individual Differences, 27, 985-1014. doi:10.1016/S0191-8869(99)00048-3

Mols, F., \& Jetten, J. (2016). Explaining the appeal of populist right-wing parties in times of economic prosperity. Political Psychology, 37(2), 275-292. doi:10.1111/pops.12258

Norpoth, H. (2016). Primary model predicts Trump victory. PS: Political Science \& Politics, 49(4), 655-658. doi:10.1017/S1049096516001323

Oesterreich, D. (2005). Flight into security: A new approach and measure of the authoritarian personality. Political Psychology, 26, 275-297. doi:10.1111/j.1467-9221.2005.00418.x

Pettigrew, T. F. (1998). Intergroup contact theory. Annual Review of Psychology, 49, 65-85. doi:10.1146/annurev.psych.49.1.65

Pettigrew, T. F. (2009). Post-racism? Putting President Obama's victory in perspective. Du Bois Review, 6(2), $279-292$. doi:10.1017/S1742058X0999018X

Pettigrew, T. F. (2015). Samuel Stouffer and relative deprivation. Social Psychology Quarterly, 78, 7-24.

Pettigrew, T. F. (2016). In pursuit of three theories: Authoritarianism, relative deprivation, and intergroup contact. Annual Review of Psychology, 67, 1-21. doi:10.1146/annurev-psych-122414-033327 
Pettigrew, T. F., \& Hewstone, M. (2017). The single factor fallacy: Implications of missing critical variables from an analysis of intergroup contact theory. Social Issues and Policy Review, 11(1), 8-37. doi:10.1111/sipr.12026

Pettigrew, T. F., \& Tropp, L. R. (2006). A meta-analytic test of intergroup contact theory. Journal of Personality and Social Psychology, 90, 751-783. doi:10.1037/0022-3514.90.5.751

Pettigrew, T. F., \& Tropp, L. R. (2008). How does intergroup contact reduce prejudice? Meta-analytic tests of three mediators. European Journal of Social Psychology, 38, 922-934. doi:10.1002/ejsp.504

Pettigrew, T. F., \& Tropp, L. R. (2011). When groups meet: The dynamics of intergroup contact. New York, NY, USA: Psychology Press.

Portelinha, I., \& Elcheroth, G. (2016). From marginal to mainstream: The role of perceived social norms in the rise of a far-right movement. European Journal of Social Psychology, 46(6), 661-671. doi:10.1002/ejsp.2224

Reicher, S., \& Haslam, S. A. (2016, November 19). The politics of hope: Donald Trump as an entrepreneur of identity. Scientific American. Retrieved from

https://www.scientificamerican.com/article/the-politics-of-hope-donald-trump-as-an-entrepreneur-of-identity

Reilly, K. (2016, November 16). Racist incidents are up since Donald Trump's election. Time Magazine. Retrieved from http://time.com/4569129/racist-anti-semitic-incidents-donald-trump

Rothwell, J., \& Diego-Rosell, P. (2016). Explaining nationalist political views: The case of Donald Trump. Unpublished Gallup Working paper, last revised November 2, 2016.

Sidanius, J., \& Pratto, F. (2001). Social dominance: An intergroup theory of social hierarchy and oppression. Cambridge, United Kingdom: Cambridge University Press.

Silver, N. (2016, May 3). The mythology of Trump's "working class" support. FiveThirtyEight. Retrieved from https://fivethirtyeight.com/features/the-mythology-of-trumps-working-class-support

Smith, H. J., Pettigrew, T. F., Pippin, G. M., \& Bialosiewicz, S. (2012). Relative deprivation: A theoretical and meta-analytic critique. Personality and Social Psychology Review, 16(3), 203-232. doi:10.1177/1088868311430825

Staples, B. (2008, November 8). Barack Obama, John McCain and the language of race. New York Times. Retrieved from http://www.nytimes.com/2009/09/22/opinion/observer

Stenner, K. (2005). The authoritarian dynamic. New York, NY, USA: Cambridge University Press.

Swyngedouw, M., \& Ivaldi, G. (2001). The extreme right utopia in Belgium and France: The ideology of the Flemish Vlaams Blok and the French front national. West European Politics, 24(3), 1-22. doi:10.1080/01402380108425450

Van Assche, J., \& Pettigrew, T. F. (2016). Comparing American and European far-right voters. Unpublished paper, Department of Developmental, Personality and Social Psychology, Ghent University, Ghent, Belgium.

Van Hiel, A. (2012). A psycho-political profile of party activists and left-wing and right-wing extremists. European Journal of Political Research, 51, 166-203. doi:10.1111/j.1475-6765.2011.01991.x

Van Hiel, A., \& Mervielde, I. (2002). Explaining conservative beliefs and political preferences: A comparison of social dominance orientation and authoritarianism. Journal of Applied Social Psychology, 32(5), 965-976. doi:10.1111/j.1559-1816.2002.tb00250.x

Wagner, U., Christ, O., Pettigrew, T. F., Stellmacher, J., \& Wolf, H. (2006). Prejudice and minority proportion: Contact instead of threat effects. Social Psychology Quarterly, 69(4), 380-390. doi:10.1177/019027250606900406 